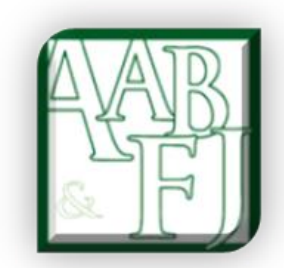

\title{
Their Control will Make or Break the Sustainable Clothing Deal - A Study of the Moderating Impact of Actual Behavioural Control on the Purchase Intention-Behaviour Gap for Sustainable Clothing in India
}

\author{
Jaspreet Kaur $^{1}$ and Neha Bhardwaj ${ }^{2}$
}

\begin{abstract}
The area of the purchase intention and purchase behaviour gap for consumers buying environmentally sustainable products with respect to the Theory of planned behaviour (TPB) framework has been studied extensively in past literature. But literature is scant when one studies the impact of 'Actual behavioural control' on the Purchase intention (PI) and purchase behaviour (PB) gap for the consumption of environmentally sustainable clothing. The TPB theory formulated by Ajzen in 1991 assumes that the actual behavioural control (ABC) will impact the purchase intention in the TPB. As there was no validated scale on the ABC in the past literature. Sheeran et al in 2003 made an attempt in testing the impact of Actual behavioural control on the purchase intention and formulate scale of Proxy measure of actual control (PMAC) in their study. Further Carrington et al. in 2010 tested the impact of the Actual behavioural control as a moderator in the purchase intention-behaviour gap qualitatively. The Empirical testing of the ABC to test the impact as a moderator in the Purchase intention-behaviour gap has never been done in the past studies. This study is the first study which analyses the impact of "Actual behavioural control" through a scale of "Proxy measure of actual behaviour" as a moderator in the PI-PB gap in the framework of the TPB for the consumption of sustainable clothing in India. Data collection has been done from Millennials of India. The research method of Structural equation modeling (SEM) has been used to assess the moderation impact of $\mathrm{ABC}$ on the purchase intention-behaviour gap. The findings of the study have shown that the PMAC positively moderates the relation of purchase intention and purchase behaviour for environmentally sustainable clothing. The outcome of the study is important to generate some crucial insights for the marketing strategies for the environmentally sustainable brands in Indian and to predict the behaviour of the Indian consumer towards such products.
\end{abstract}

Keywords: Actual Behavioural Control, Theory of Planned Behaviour, Sustainable Consumption JEL Classification: M30, M31

\footnotetext{
${ }^{1}$ Pearl Academy, India

${ }^{2}$ Indian Institute of Management, Rohtak, India.
} 


\section{INTRODUCTION}

In the year 2015, 'The 2030 Agenda for sustainable development' was adopted by the U.S., which provided a set of 17 Sustainable Development Goals (SDGs). An outcome of The Paris Agreement 2016, the SDG's aim to integrate sustainability at the strategy level with all stakeholders (Wadera $\&$ Kaur, 2019). They serve as a guide towards managing and disclosing environmental, social and governance issues (Armstrong, 2020; De Silva Lokuwaduge et. al., 2020). One among these SDG's was to tackle climate change and work to preserve the environment. Further the 'consumer concern' about the environmental impact of consumption of unethical products has brought in an increased demand for environmentally sustainable clothing.

'Environmentally sustainable clothing' could be defined as all the clothing products which are environmentally friendly .At the same time these products should also be ecologically safe and should not cause any harm to the environment (D'Souza et al., 2007).

A lot of attention has been given in the past research to the 'consumer concern' for environment. This 'concern' is crucial as the customer is crucial in formulating any marketing strategy (Kaur, 2014).It is this concern which has led to an increase in 'sustainable brands' in India. But is this concern 'actually true', if we practically talk of converting the same into 'Actual Behaviour' of purchase, in the real time scenario, is the question this study answers.

Where studies in Western nations have proven that the environment concern does positively impact the consumption behaviour, for example sales of in U.S has seen an increase of $44 \%$ in the year 2002 and that of UK consumers has increased by 15\% in the year 2003 (Williams et al. 2005). Even when it comes to the sustainable clothing products, western countries have shown that there is a positive impact of environment concerns on the purchase of sustainable clothing (Williams et al., 2005). A study by Connolly and Shaw (2006) and Shaw and Shui (2002) explains the impact of activist groups and awareness in the increased of ethical consumption.

But there are yet other reports which show that there still exists a purchase intention-behaviour gap in the market when it comes to sustainable clothing. When it comes to challenges in the fashion market, sustainability has been listed as the biggest challenge to catch up with in the fashion market (McKinsey, 2020).The McKinsey State of Fashion 2020 report states that although activist movements are making consumers aware about the environmental impact of clothing. The shocking fact is that still a relativelysmall percentage of consumers would volunteer to buy more for sustainable products. (McKinsey, 2020)

Past studies done on ethical purchase of clothing, have also supported the industry research data as they have shown that the consumers are limited in making ethical choices (Dickson, 2001; Shaw \& Duff, 2002; Tomollilo \& Shaw, 2004). In a study done by Shaw and Duff (2002), it was found that ethically concerned consumers have little or no information about the ethical choices of clothing. They were also not aware of the consequences of their actions which was buying unethical products. Thus a few of the consumers may be concerned but are not aware that the clothing they are purchasing is sustainable or not. The crucial outcome of the study was that the few customers who are aware of the consequences of their purchase lacked the 'Behavioural control' on their actions of unethical purchase. Findings from another study showed that consumers tend to prioritise their ethical concerns to a certain number of consumption choices with which they can 'cope' up (Shaw \& Clarke, 2000). The study by Shaw and Duff (2002) has proven further that the lack of availability of a sustainable product or the dearth of choice in ethical 
alternatives of clothing is a deterrent to purchase of sustainable clothing. The consumers in the study stated that they felt that the sustainable clothing products were not up to date with the current fashion trend and were comparatively expensive as compared to their non-sustainable counterpart brands (Shaw and Duff 2002). Thus although a set of consumer might show an intention to buy, the same might not convert into an actual behaviour (Newholm, 2005; Belk et.al., 2005).

\section{Research gap:}

Where many studies try and analyse the reasons of this the purchase intention and behaviour gap for ethical products (Carrington et al., 2010; Scholz et al., 2008; Auger and Devinney, 2007; Tomolillo and Shaw, 2004), the role of 'actual behavioural control'(ABC) is crucial in predicting the purchase intention-behaviour gap while purchasing the sustainable products (Sheeran et al., 2003; Andorfer and Liebe, 2012). 'Actual behavioural control' can be defined as measure of the control a person shows on his performance (in this case purchase of an unethical product) (Ajzen, 2002).

Thus the whole effort in manufacturing and marketing the sustainable products would get wasted in case the consumer behaviour is not aligned with it (Shaw et al., 2006; Hassan et al., 2014; Kumar et al. 2017). At the same time past research exploring ethical issues for environmentally sustainable clothing is not sufficiently studied (Dickson, 2005; Shaw and Duff, 2002; Fukukawa, 2003).

The impact of $\mathrm{ABC}$ is yet to be empirically tested as the past studies in literature on the impact of $\mathrm{ABC}$ are purely conceptual and the quantitative insights would be potential in the validation of the qualitative studies of ABC (Carrington et. al., 2010; Hassan et al., 2014).

The main aim of this study is to empirically test the moderating impact of 'Actual behavioural control' on the Purchase intention-behaviour gap for environmentally sustainable products for this segment of 'concerned' consumers in India. The findings of the study will help sustainable clothing brands in India to formulate an appropriate strategy for consumers in India from the implications of the 'actual behavioural control' on the Purchase intention-behaviour gap.

\section{RESEARCH DESIGN AND METHODOLOGY:}

A systematic review was conducted with empirical studies to extend the conceptual framework of the theory of Planned behaviour and explain the mediating effect of Actual behavioural control on the Purchase intention behaviour gap.

\section{Research design and methodology:}

A descriptive research design has been applied in the research paper. A structured questionnaire based survey was used to collect data and examine the relationships postulated through conceptual framework in Figure 1. The conceptual framework presents direct, mediated and moderated relationships of the study. The research was based in India, a developing nation, which also offers numerous opportunities in the field of environmental sustainability. The consultancy firm, Mckinsey, in their annual fashion report - 'The State of Fashion 2019 and 'The State of Fashion 2020 , identified 'sustainability' as the top theme for Indian fashion industry.

Data for the study were collected from graduate and post graduate fashion management students in India. The respondents of the study, were called for seminars are briefed about key terminologies used in the questionnaire, such as sustainable clothing, before they actually filled the questionnaire. 
This ensured that each respondent was aware about the theme of this study. Also, further there was a filtering was done for the respondents who had no idea or who had not come across sustainable clothing products or brands ever. Therefore, data was collected from only those respondents, who in some way had prior exposure to sustainable product. The selection of fashion management students as sample for this study could be justified based on the fact that young adults are future consumers, while also holding the capability to bring about a change in consumption patterns (Kumar et. al., 2017; McKinsey, 2020).

The sample characteristics of the study are presented through Table 1. A total of 249 responses were obtained of which 237 were found to be usable for the study. The sample for this study consisted of $41.4 \%$ males and $58.6 \%$ females. Also, as can be deciphered from the table, a majority of the respondents $(84.4 \%)$ belong to the age group of 18-23 years, thereby representing Generation Z (McKinsey, 2020).

Table 1: Sample Characteristics

\begin{tabular}{|l|l|l|l|}
\hline Sample Characteristics & Frequency & Percentage \\
\hline \multirow{3}{*}{ Gender } & Male & 98 & 41.4 \\
\cline { 2 - 4 } & Female & 139 & 58.6 \\
\hline \multirow{4}{*}{ Age Group } & $18-23$ years & 200 & 84.4 \\
\cline { 2 - 4 } & $24-29$ years & 27 & 11.4 \\
\cline { 2 - 4 } & $30-35$ years & 4 & 1.7 \\
\cline { 2 - 4 } & Above 35 years & 5 & 2.1 \\
\hline
\end{tabular}

\section{LITERATURE REVIEW}

\section{Role of Actual behavioural control in the Theory of planned behaviour:}

The TPB of theory of planned behaviour became popular, as an extension or modification of the theory of reasoned action (Dewi et. al., 2020) which aimed at studying the voluntary behaviours. A voluntary behaviour could be Defined as a behaviour over which the consumer portrays a good control (Ajzen, 1985). It has but been noticed that a consumer may want to buy a product which means his intention to buy a product is present, but in real life situation while actually performing the behaviour the consumer may not do so. This is the case with sustainable clothing too. Many past studies have explained this behavioural aspect of consumer like Ajzen (1985) extending the theory of reasoned action(TBA) to introduce a construct of perceived behavioural control (PBC). PBC could be explained as a person's perception as to how much control does he have, on performing a certain behaviour. This but might not be the case in the actual consumption scenario, and thus could bring in a difficulty, in predicting the actual behaviour of a consumer towards ethical products(Ajzen \& Madden, 1986). Ajzen and Madden(1986) have not reported a direct causal effect for the construct perceived behavioural control for the TPB. Ajzen \& Madden (1986) but have given a correct measure of actual control. The same was not found to be feasible, as two individuals could have similar actual control ability (ABC) but could have a difference in perception of the measure of control of the consumer (PBC). Thus authors suggest the 'actual control' not the perceived behavioural control as a causal determinant of behaviour towards ethical products(Sheeran et al. 2003; Notani,1998). Thus the assumption that the PBC could be used as a proxy for actual behavioural control (ABC) to study the relation of purchase intentions actual purchase behaviour is inaccurate (Kraft et al., 2005; Armitage and Conner, 2001). Thus Sheeran et al.(2003) validated a scale of Proxy measure of actual behaviour and studied the direct moderating impact of $\mathrm{ABC}$ (not $\mathrm{PBC}$ ) on the intention -behaviour gap. Still the extant literature is full of 
research where the PBC has been used as a proxy of actual behaviour and its impact has been studied on Purchase intention of unethical products.

Very few studies have been seen in the past and extant literature which cater to practically measuring the impact of the ABC (and not PBC) on the purchase intention in the TPB model. Dunn et al. (2011) has tried to study the effect of $A B C$ on purchase intention of consumption of fast food in an Australian sample. The results of the study indicated that ABC was positively related to the purchase intentions of the respondents. Further Hassan et al. (2014) found that there is no evident mediating impact of $\mathrm{ABC}$ on the purchase intention-behaviour gap in their study on purchase of sweatshop clothing.

But none of these studies have analysed the moderating impact of $\mathrm{ABC}$ the purchase intentionbehaviour gap when it comes to the consumption of environmentally sustainable clothing in India. Moreover none of the studies in the past literature have made use of the PMAC scale developed by Sheeran et al.(2003) to study the impact of ABC on the purchase intention. The present research paper will be first of its kind which will try and analyse the mediating impact of $\mathrm{ABC}$ on the purchase intention-behaviour gap for the consumption in sustainable clothing in India with the help of the PMAC scale developed by Sheeran et al. (2003).

\section{Conceptual Framework}

As per the TPB, the consumer's purchase intention is positively affected by the Attitude and Subjective norms towards the behaviour. Attitude can be defined as the extent to which a consumer has a favorable or unfavorable evaluation towards a behaviour (Ajzen, 1991). A positive attitude (i.e. perceive cost and benefits) towards a behaviour can impact the purchase intention towards purchase of environmentally sustainable products (Ajzen, 2015; Bamberg et. al., 2007; Chu and Chiu, 2003; Klockner and Blobaum, 2010).Attitude of the consumer could further get influenced by the level of beliefs about the likely outcome.

At the same time Subjective norms can be defined as the perceived social pressure to perform or not perform a given behaviour. The same can be detected by the normative pressure of the consumers relevant others (Ajzen, 2013; Kaiser et al., 1999; Nigbur et al., 2010).

H1: Subjective norms positively affect the purchase intention of sustainable clothing

H2: Attitude positively influences Purchase Intention towards environmentally sustainable clothing

As per Ajzen and Madden(1986) and Fishbein and Ajzen(1975) studied the Purchase intention mediates the relation between attitude and final purchase behaviour. Past studies have shown that the consumer's intentions will directly impact the actual purchase behaviour (Fukukawa, 2003). David et al. (2012) in the study on purchase behaviour towards recycled products found a positive impact of Purchase intention on the Purchase behaviour of customers. As per Ozcaglar-Toulouse et al. (2006) the actual purchase behaviour could directly effect the consumer's intention to conduct the behaviour. Further a study by Kumar et al.(2017) on environmental sustainable products concludes that the Purchase intention does alter the purchase behaviour of the consumers. Past literature does show that purchase intention impacts the Purchase behaviour in relation Green products and clothing too(Sethi et al., 2017; Kaur et al., 2018). 
H3: Purchase Intentions positively influence Purchase Behaviour towards environmentally sustainable clothing

H4: Purchase Intentions mediate the relationship between Subjective Norms and Purchase Behaviour

H5: Purchase Intentions mediate the relationship between Attitude and Purchase Behaviour

Ajzen (1991) formulated construct of Perceived behavioural control (PBC) as the behavioural intention could convert to an actual behaviour in case the behaviour shows a volitional control(which here is control on buying unethical products). As per this definition it can be assumed that the actual control moderates the intention- behaviour relation. So also as per Ajzen(1991) and Sheeran et al. (2003), as the actual control increases, one could better predict the intention of a consumer for purchase of an ethical product actually converted to a purchase behaviour. Thus Past studies have proven that behavioural control moderates the intentions and behaviour relation (De Pelsmacker and Janssens, 2007).

Further Carrington et al. (2010) reported a positive influence of 'Actual behavioural control' on the Purchase intention-behaviour gap.

H6: Proxy Measure to Actual Control interacts to moderate the relationship between Purchase Intentions and Purchase Behaviour towards environmentally sustainable clothing.

Figure 1 shows the proposed conceptual model for the study.

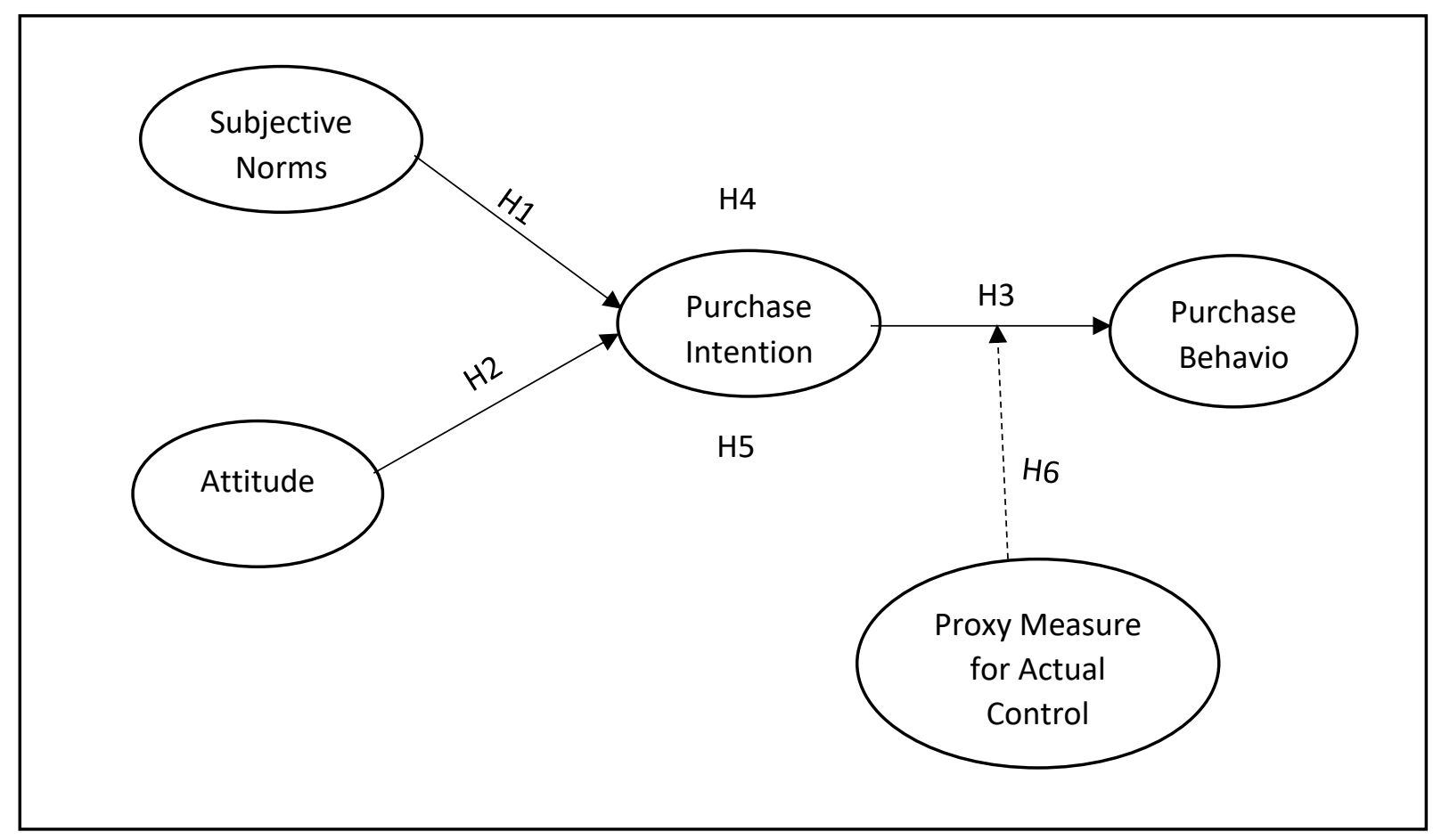

\section{Measurement Scales Used}

The study examines the relation among four crucial constructs. Validated scales from prior studies were adapted for the present study and have been adapted for environmentally sustainable clothing. All scales were measured on a 5-point likert scale. The ABC scale has been adapted from the 
Proxy measure of actual behaviour(PMAC) scale validated by Sheeran et al.(2003) and consists of three items.

Attitude(Att) was measured on a three item scale which was developed by Valle et al. (2005). The subjective norm(SN) was measured on a three item scale developed by Vermier and Verbeke (2006). The purchase intention (PI) was measured by a four item scale developed by Baker and Churchill (1977). The purchase behaviour(PB was measured by a scale developed by Schlegelmilch et al. (1996).

Structural Equation Modelling was used to test for relationship identified in the conceptual framework of this study. The two-stage process was adopted, which includes investigating the measurement model along with structural model using SPSS-AMOS (Anderson \& Gerbing, 1988).

\section{Validity \& Reliability}

Table 2 lists down the values of Average Variance Extracted (AVE) and Cronbach's Alpha for each construct of the study. Scale reliability corresponding to each of the constructs was measured using Cronbach's Alpha. Further, item-to-total correlations assessed reliability of each individual scale items. The reliability measures are presented in Table 2, along with scale items for each of the constructs of this study. One item from Purchase Intention(PI) and one from Purchase Behaviour(PB) had to be deleted to improve reliability of the scales. Taber (2016) identified a range of descriptors, from prior literature, to interpret cronbach's alpha values. Based on these descriptors, the Cronbach's Alpha values for the constructs of this study may be categorised as reasonable / adequate (0.67-0.87) for Purchase Decision Behaviour and high (0.73-0.95) or fairly high (0.76-0.95) for other constructs of this study. All constructs returned a Cronbach's Alpha value greater than 0.6, which was considered to be satisfactory(Hair et. al., 2010).

Table 2: Scale items and reliability measures for the study constructs

\begin{tabular}{|c|c|c|}
\hline Construct & Measures & $\begin{array}{l}\text { Item-to- } \\
\text { total } \\
\text { Correlation }\end{array}$ \\
\hline \multirow{3}{*}{$\begin{array}{l}\text { Attitude } \\
\text { Cronbach's Alpha - 0.862; AVE } \\
-0.687\end{array}$} & $\begin{array}{l}\text { I believe that use of environmentally sustainable clothing by me will help in } \\
\text { reducing pollution and also help in improving the environment. }\end{array}$ & 0.692 \\
\hline & $\begin{array}{l}\text { I believe that use of environmentally sustainable clothing by me will help in } \\
\text { reducing wasteful use of natural resources. }\end{array}$ & 0.806 \\
\hline & $\begin{array}{l}\text { I believe that use of environmentally sustainable clothing by me will help in } \\
\text { conserving natural resources. }\end{array}$ & 0.725 \\
\hline \multirow{3}{*}{$\begin{array}{l}\text { Subjective Norms } \\
\text { Cronbach's Alpha - 0.860; AVE } \\
-0.677\end{array}$} & $\begin{array}{l}\text { My friends expect me to engage in environmentally sustainable clothing usage } \\
\text { behaviour. }\end{array}$ & 0.748 \\
\hline & $\begin{array}{l}\text { My family expects me to engage in environmentally sustainable clothing usage } \\
\text { behaviour. }\end{array}$ & 0.777 \\
\hline & $\begin{array}{l}\text { My society expects me to engage in environmentally sustainable product usage } \\
\text { behaviour. }\end{array}$ & 0.688 \\
\hline \multirow{3}{*}{$\begin{array}{l}\text { Purchase Intention* } \\
\text { Cronbach's Alpha }-0.826 ; \text { AVE } \\
-0.678\end{array}$} & $\begin{array}{l}\text { I would buy environmentally sustainable clothing if I happen to see them in a } \\
\text { store. }\end{array}$ & 0.655 \\
\hline & $\begin{array}{l}\text { I would actively seek out environmentally sustainable clothing in a store in order } \\
\text { to purchase it. }\end{array}$ & 0.726 \\
\hline & $\begin{array}{l}\text { I would patronise and recommend the use of environmentally sustainable } \\
\text { clothing }\end{array}$ & 0.697 \\
\hline \multirow{3}{*}{$\begin{array}{l}\text { Purchase Behaviour* } \\
\text { Cronbach's Alpha - 0.669; AVE } \\
-0.501\end{array}$} & $\begin{array}{l}\text { If I understand the potential damage to the environment that some clothing can } \\
\text { cause, I do not purchase those clothing. }\end{array}$ & 0.505 \\
\hline & $\begin{array}{l}\text { I don't buy a clothing if the company which sells it is environmentally } \\
\text { irresponsible. }\end{array}$ & 0.505 \\
\hline & For me, buying ethical fashion clothing is very easy & 0.591 \\
\hline
\end{tabular}




\begin{tabular}{|c|c|c|}
\hline \multirow{2}{*}{$\begin{array}{l}\text { Proxy Measure for Actual } \\
\text { Control } \\
\text { Cronbach's Alpha-0.783; AVE } \\
-0.558\end{array}$} & $\begin{array}{l}\text { I have complete control in decision making when it comes to buying ethical } \\
\text { fashion clothing }\end{array}$ & 0.581 \\
\hline & If I want to, I can easily buy ethical fashion & 0.700 \\
\hline
\end{tabular}

Note: * Items deleted to improve validity (Vohra \& Bhardwaj, 2019)

To verify the validity of this study, content validity, convergent and discriminant validity were assessed. The content validity was established by taking advise from 5 experts two Academicians from the domain of business ethics and 3 industry experts who had an experience in selling sustainable products for at least 5 years in India were shown the validated scales for their advise. A few changes as suggested by the experts were made to the instrument. The instrument was further tested with 50 samples as a pilot test for any ambiguity in understanding the meaning of the items. The instrument was found to be reliable with appropriate Cronbach values in the pilot test. Finally the questionnaire was filled by the final 237 respondents. The convergent and discriminant values was assessed with the help of the AVE values. The AVE (Average Variance Extracted) values of each of the constructs of this study were also found to be greater than 0.5 (Table 3). This established convergent validity of the measures was adapted for the study (Bagozzi \& Yi, 1988). Further, Fornell \& Larcker (1981) identified that the square root of AVE has to be greater than the correlation between constructs, so as to establish discriminant validity. Similar approach was also adopted by other prior studies (Vohra \& Bhardwaj, 2017; Kim et. al., 2013).

Table 3: Discriminant Validity \& Correlations among each constructs

\begin{tabular}{|c|c|c|c|c|c|c|c|c|c|c|c|}
\hline & Mean & SD & CR & AVE & MSV & $\begin{array}{l}\operatorname{MaxR}( \\
\text { H) }\end{array}$ & $\begin{array}{l}\text { Purchase_ } \\
\text { Behaviour }\end{array}$ & $\begin{array}{l}\text { Attitu } \\
\text { de }\end{array}$ & $\begin{array}{l}\text { Purchase } \\
\text { _Intention }\end{array}$ & $\begin{array}{l}\text { Subj_} \\
\text { Norm }\end{array}$ & PMAC \\
\hline $\begin{array}{l}\text { Purchase } \\
\text { Behaviour }\end{array}$ & 3.12 & .743 & 0.667 & 0.501 & 0.498 & 0.669 & 0.708 & & & & \\
\hline Attitude & 3.64 & .674 & 0.868 & 0.687 & 0.483 & 0.884 & 0.429 & 0.829 & & & \\
\hline $\begin{array}{l}\text { Purchase } \\
\text { Intention }\end{array}$ & 2.76 & .656 & 0.861 & 0.678 & 0.483 & 0.902 & 0.654 & 0.695 & 0.823 & & \\
\hline $\begin{array}{l}\text { Subjective } \\
\text { Norm }\end{array}$ & 2.76 & .867 & 0.862 & 0.677 & 0.498 & 0.880 & 0.706 & 0.369 & 0.646 & 0.823 & \\
\hline PMAC & 3.39 & .804 & 0.791 & 0.558 & 0.450 & 0.797 & 0.671 & 0.406 & 0.488 & 0.649 & 0.747 \\
\hline
\end{tabular}

\section{Structural Model}

The structural model was assessed on SPSS - AMOS, and the results obtained are presented in Table 4.

The conceptual framework of this study proposes that Attitude and Subjective Norms Influence Purchase Behaviour mediated through Purchase Intention. Also, Proxy Measure for Actual Control is identified to be moderating the relationship between Purchase Intention and Purchase Behaviour. The same can be seen in the Regression results in Table 4. 
Table 4: Regression Results

\begin{tabular}{|c|c|c|c|}
\hline & B & Beta & p-value \\
\hline \multicolumn{4}{|l|}{$\begin{array}{l}\text { Purchase Behaviour } \\
\left(\mathbf{R}^{2}=\mathbf{0 . 5 6 0}\right)\end{array}$} \\
\hline Purchase Intention & 0.35 & 0.748 & $* * *$ \\
\hline \multicolumn{4}{|l|}{$\begin{array}{l}\text { Purchase Intention } \\
\left(\mathbf{R}^{2}=\mathbf{0 . 7 2 9}\right)\end{array}$} \\
\hline Attitude & 0.536 & 0.550 & $* * *$ \\
\hline Subjective Norms & 0.350 & 0.462 & $* * *$ \\
\hline
\end{tabular}

The results indicate that the model explains $56 \%$ variation in Purchase Behaviour $\left(\mathrm{R}^{2}=0.560\right)$ and $72.9 \%$ variation in Purchase Intention $\left(\mathrm{R}^{2}=0.729\right)$. Also, both Attitude $(\beta=0.550)$ and Subjective Norms $(\beta=0.462)$ were found to be significantly influencing Purchase Intention. Further, Purchase Intention was found to be having a significant influence on Purchase Decision Behaviour. The summary of the Structural model results is shown in Table 5.

Table 5: Summary of Structural Model Results

\begin{tabular}{|l|l|l|l|}
\hline \multicolumn{2}{|l|}{ Hypothesis } & Result \\
\hline H1 & $\begin{array}{l}\text { Subjective Norms positively influence Purchase Intentions } \\
\text { towards environmentally sustainable clothing }\end{array}$ & Significant & $\begin{array}{l}\beta= \\
(* * *)\end{array}$ \\
\hline H2 & $\begin{array}{l}\text { Attitude positively influences Purchase Intention towards } \\
\text { environmentally sustainable clothing }\end{array}$ & Significant & $\begin{array}{l}\beta=0.550 \\
(* * *)\end{array}$ \\
\hline H3 & $\begin{array}{l}\text { Purchase Intentions positively influence Purchase Behaviour } \\
\text { towards environmentally sustainable clothing }\end{array}$ & Significant & $\begin{array}{l}\beta= \\
(* * *)\end{array}$ \\
\hline
\end{tabular}

\section{Mediating Effect of Purchase Intention towards Purchase Behaviour}

This study proved Purchase Intentions to have a mediating the impact of Attitude and Subjective Norms on Purchase Behaviour.

Table 6: Mediation Effect Results

\begin{tabular}{|l|l|l|l|l|l|l|}
\hline \multirow{2}{*}{ Relationship } & \multirow{4}{*}{$\begin{array}{l}\text { Direct Effect } \\
(\text { p-value })\end{array}$} & \multicolumn{3}{|l|}{ Indirect Effects } & \multirow{2}{*}{ Mediation } \\
\cline { 3 - 7 } & & p-value & LLCI & ULCI & Effect Size & \\
\hline SN $\rightarrow$ PI $\rightarrow$ PB & Sig. & Sig. & .1515 & .2660 & .2054 & Partial Mediation \\
\hline Att. $\rightarrow$ PI $\rightarrow$ PB & $.1699(N S)$ & Sig. & .5464 & .8057 & .6672 & Complete Mediation \\
\hline
\end{tabular}

The mediation results identified that Subjective norms $(\beta=0.5237 ; \mathrm{p}<0.05)$ significantly influence Purchase Intention. Further, the results also indicated for both Purchase Intention $(\beta=0.3923$; $\mathrm{p}<0.05)$ and Subjective Norms $(\beta=0.4980 ; \mathrm{p}<0.05)$ to be significantly influencing Purchase Behaviour. Also, the indirect effect of Subjective norms on Purchase Behaviour was found to be positive $($ BootLLCI $=.1515$ and BootULCI $=0.2660$ ). The results, therefore, indicate for Purchase 
Intention to be partially mediating the relationship between Subjective Norms and Purchase Behaviour (Table 6).

Next, the study identified for Purchase Intention to be mediating the relationship between Attitude and Purchase Behaviour. The results indicated that Attitude $(\beta=0.7238 ; p<0.05)$ significantly influences Purchase Intention. Further, the results also indicated that while Purchase Behaviour is significantly impacted by Purchase Intention $(\beta=0.9217 ; p<0.05)$; the impact of attitude on the same was found to be non-significant $(\beta=-0.0979 ; p>0.05)$. Thus, the direct effect of Attitude on Purchase Behaviour in the presence of Purchase Intention was found to be non-significant. Next, the indirect effect of Attitude on Purchase Behaviour was found to be positive (BootLLCI $=.5464$ and BootULCI $=.8057$ ). The study, therefore, concludes that Purchase Intentions completely mediate the impact of Attitude on Purchase decision Behaviour (Table 6).

\section{Estimate of Moderating Effects}

Lastly, the study tested for Proxy Measure for Actual Behavioural Control (PMAC) to be moderating the relationship between Purchase Intention and Purchase Decision Behaviour. The interaction effects of Purchase Intention with PMAC were found to be significant (LLCI = .0540; ULCI $=.2091 ; \mathrm{p}=0.0010)$. Thus, PMAC significantly moderates the relationship. Also, the conditional effects were found to be significant $(\mathrm{p}<0.05)$ at all levels of PMAC. The moderation effects are depicted in Figure 2.

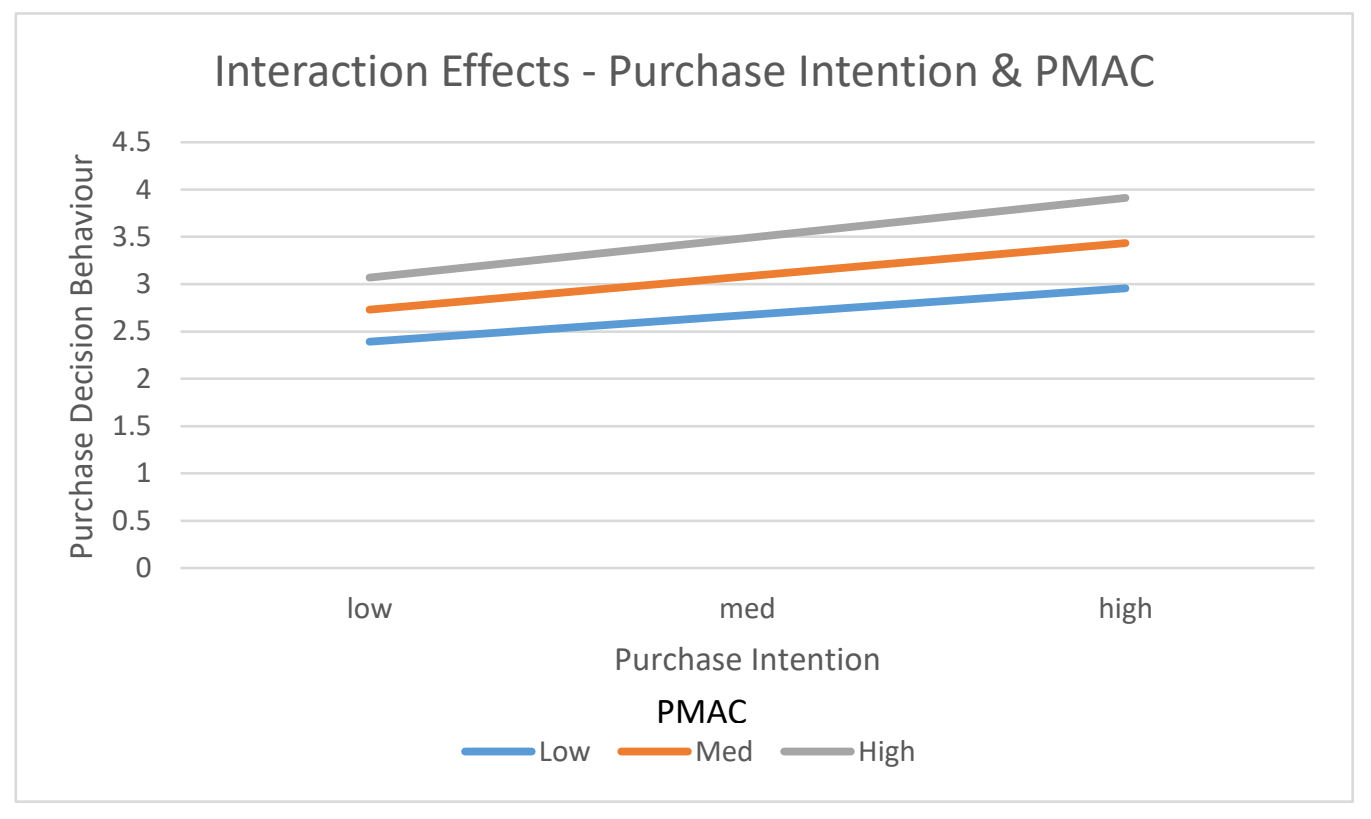

Figure 2 indicates that higher the purchase intentions, more pronounced are its effects on purchase behaviour in the presence of PMAC.

Table 7 sumarises the results of hypothesis testing for this study. The data for the study supported all hypotheses of the study. Further, while purchase intentions were found to be partially mediating the relationship between purchase intentions and purchase behaviour; they completely mediate the relationship between attitude and purchase behaviour. The moderation effect of PMAC was also found to be significant on the relationship between purchase intentions and purchase behaviour. 
Table 7: Hypothesis Testing Results

\begin{tabular}{|l|l|l|}
\hline \multicolumn{2}{|l|}{ Hypothesis } & Result \\
\hline H1 & $\begin{array}{l}\text { Subjective Norms positively influence Purchase Intentions } \\
\text { towards environmentally sustainable clothing }\end{array}$ & Significant \\
\hline H2 & $\begin{array}{l}\text { Attitude positively influences Purchase Intention towards } \\
\text { environmentally sustainable clothing }\end{array}$ & Significant \\
\hline H3 & $\begin{array}{l}\text { Purchase Intentions positively influence Purchase Behaviour } \\
\text { towards environmentally sustainable clothing }\end{array}$ & Significant \\
\hline H4 & $\begin{array}{l}\text { Purchase Intentions mediate the relationship between Subjective } \\
\text { Norms and Purchase Behaviour }\end{array}$ & $\begin{array}{l}\text { Partial } \\
\text { mediation }\end{array}$ \\
\hline H5 & $\begin{array}{l}\text { Purchase Intentions mediate the relationship between Attitude } \\
\text { and Purchase Behaviour }\end{array}$ & $\begin{array}{l}\text { Complete } \\
\text { mediation }\end{array}$ \\
\hline H6 & $\begin{array}{l}\text { Proxy Measure to Actual Control interacts to moderate the } \\
\text { relationship between Purchase Intentions and Purchase } \\
\text { Behaviour towards environmentally sustainable clothing }\end{array}$ & $\begin{array}{l}\text { Significantly } \\
\text { Moderated }\end{array}$ \\
\hline
\end{tabular}

The CFA model that included all constructs in the model, resulted in good fit indices $-\mathrm{CFI}=0.91$ and RMSEA $=0.078$ (Hair et. al., 2010).

\section{DISCUSSION AND FUTURE WORK}

This study validated the moderating impact of the ABC on the PI-PB gap. The results have shown that BAC partially moderates the PI-PB relation. Thus the ABC of a consumer plays a very pertinent role in the purchase intention towards an environmentally sustainable clothing products changing to the final purchase behaviour of the environmentally sustainable clothing products. These results are in line with the previous studies where $\mathrm{ABC}$ has shown an impact on the purchases behaviour of consumers (Hassan et al., 2016; Sheeran et al., 2003; Carrington et al., 2010).

The prediction of the behaviour of the consumers in India on the basis of impact of Actual behavioural control on the intention-behaviour gap will provide a crucial insights for the sustainable clothing brands in the Indian market. As Actual behavioural control is the consumers' capacity to perform a given behaviour and the extent to which the consumer can control their inner abilities (in this case not to buy an unsustainable clothing products),the same will be crucial in formulating marketing strategies for the sustainable clothing brands. The sustainable clothing brands could use these inputs and modify their positioning strategies so as to increase this Actual behavioural control among target consumers when it comes to rejecting unsustainable clothing brands. This type of positioning could also lead to forming a negative attitude towards unsustainable clothing brands so that the $\mathrm{ABC}$ of consumers towards them could increase. Thus the consumers will be able to take informed decisions. Further the sustainable clothing brands could inculcate the findings of the study to build their retailing strategy for the in-store sales. The store manager and sales person have to explain the relevance of sustainable clothing to the consumers and increase their $\mathrm{ABC}$ towards not buying unsustainable clothing. This could help sustainable clothing companies to build a strong competition strategy against the unsustainable brands in the Indian market. Further the Marketing mix could be changed with massive promotions stressing on the 'sustainability' component for clothing and reducing price for 'sustainable 
clothing' products to lure the consumer towards sustainable clothing purchase. This would further help increase the $\mathrm{ABC}$ of the Indian consumers towards not purchasing unsustainable clothing.

\section{Future scope and Limitations}

The limitations of the study are that the sample was restricted to the region of New Delhi. Also as the understanding of 'sustainable fashion' was found to be more in fashion management students, the study limited itself to the survey of fashion management students. This study can be taken further to all the management students in India. Further a proper actual behavioural scale could be constructed for India for sustainable clothing purchase which has still not been done(Sheeran et al., 2003).Further some cultural factors(Belk, 2005) and religiosity could also be studied as a moderator along with ABC to the PI-PB gap for sustainable products(Shaw et al., 1999)

\section{References:}

Ajzen, I. (2015). The theory of planned behaviour is alive and well, and not ready to retire: a commentary on Sniehotta, Presseau, and Arujo-Saores. Health Psychology Review, 9(2), 131-137. https://doi.org/10.1080/17437199.2014.883474

Ajzen, I. (2002). Percieved Behavioural Control, Self-Efficacy, Locus of Control, and the Theory of Planned Behaviour. Journal of Applied Social Psychology, 32(4), 665-683. https://doi.org/10.1111/j.1559-1816.2002.tb00236.x

Ajzen, I. (1991). The theory of planned behaviour. Organizational Behaviour and Human Decision Processes, 50(2), 179-211. https://doi.org/10.1016/0749-5978(91)90020-T

Ajzen, I. (1985). From intention to actions: A theory of planned behaviour. In J. Kuhl \& J. Beckman (Eds.), Action control: From cognitions to behaviour (pp. 11-39). New York, NY: Springer-Verlag. https://doi.org/10.1007/978-3-642-69746-3_2

Ajzen, I., \& Sheikh, S. (2013). Action versus inaction: Anticipated affect in the theory of planned behaviour. Journal of Applied Social Psychology, 43(1), 155162. https://doi.org/10.1111/j.1559-1816.2012.00989.x

.Ajzen, I., \& Madden, T. J. (1986). Prediction of goal-directed behaviour: Attitudes, intentions and perceived behavioural control. Journal of Experimental Social Psychology, 22, 453- 474. https://doi.org/10.1016/0022-1031(86)90045-4

Ajzen, I., \& Fishbein, M. (1975). Attitude-behaviour relations: a theoretical analysis and review of empirical research. Psychological Bulletin, 84, 888-918. https://doi.org/10.1037/0033$\underline{2909.84 .5 .888}$

Anderson, J. C., \& Gerbing, D. W. (1988). Structural equation modeling in practice: A review and recommended two-step approach. Psychological Bulletin, 103(3). https://doi.org/10.1037/0033-2909.103.3.411

Andorfer, V., \& Liebe, U. (2012). Research on fair trade consumption-A review. Journal of Business Ethics, 106(4), 415-435. https://doi.org/10.1007/s10551-011-1008-5 
Armitage, C. J., \& Conner, M. (2001). Efficacy of the theory of planned behaviour: A metaanalytic review. British Journal of Social Psychology, 40, 471495. https://doi.org/10.1348/014466601164939

Armstrong, A. (2020). 'Ethics and ESG', Australasian Accounting, Business and Finance Journal, 14(3), 2020, 6-17. http://dx.doi.org/10.14453/aabfj.v14i3.2

Auger, P., \& Devinney, T. M. (2007). Do What Consumers Say Matter? The Misalignment of Preferences. Journal of Business Ethics, 76, 361-383. https://doi.org/10.1007/s10551-0069287-y

Auger, P., Burke, P., Devinney, T. M., \& Louviere, J. J. (2003). What Will Consumers Pay for Social Product Features?. Journal of Business Ethics, 42, 281-304. https://doi.org/10.1023/A:1022212816261

Bagozzi, R. P., \& Yi, Y. (1988). On the evaluation of structural equation models. Journal of the Academy of Marketing Science, 16(1), 74-94. https://doi.org/10.1007/BF02723327

Baker, M. J., \& Churchill, G. A. (1977). The impact of physically attractive models on advertising evaluations. Journal of Marketing Research, 14(4), 538-555. https://doi.org/10.1177/002224377701400411

Bamberg, S., \& Möser, G. (2007). Twenty years after Hines, Hungerford, and Tomera: A new meta-analysis of psycho-social determinants of pro-environmental behaviour. Journal of Environmental Psychology, 27(1), 14-25. https://doi.org/10.1016/i.jenvp.2006.12.002

Belk, R., Devinney, T. M. \& Eckhardt, G. (2005). Consumer Ethics Across Cultures'. Consumption, Markets and Culture, 8(3), 275-289. https://doi.org/10.1080/10253860500160411

Carrington, M. J., Neville, B. A., \& Whitwell, G. J. (2010). Why ethical consumers don't walk the talk: Towards a framework for understanding the gap between the ethical purchase intentions and actual buying behaviour of ethically minded consumers. Journal of Business Ethics, 97, 139-158. https://doi.org/10.1007/s10551-010-0501-6

Connolly, J., \& Shaw, D. (2006) 'Identifying Fair Trade in Consumption Choice', Journal of strategic marketing, 14, 353-368. https://doi.org/10.1080/09652540600960675

Chu, P., \& Chiu, J. (2003), 'Factors influencing household waste recycling behaviour: Test of an integrated model', Journal of Applied Social Psychology, 33, 604626. https://doi.org/10.1111/j.1559-1816.2003.tb01915.x

D’Souza, C., Taghian, M., Lamb, P., \& Peretiatko, R. (2007), 'Green decisions: demographics and consumer understanding of environmental labels', International Journal Consumer Studies, 31(4), 371-376. https://doi.org/10.1111/j.1470-6431.2006.00567.x

De Silva Lokuwaduge, C. S., Smark, C., \& Mir, M. (2020). 'Sustainable Development Goals and Businesses as Active Change Agents', Australasian Accounting, Business and Finance Journal, 14(3), 1-5. http://dx.doi.org/10.14453/aabfj.v14i3.1 
De Pelsmacker, P., \& Janssens, W. (2007), 'A Model for Fair Trade Buying Behaviour: The Role of Perceived Quantity and Quality of Information and Product-Specific Attitudes', Journal of Business Ethics, 75, 361-380. https://doi.org/10.1007/s10551-006-9259-2

Dewi, V., Febrian, E., Effendi, N., \& Anwar, M. (2020). 'Financial Literacy among the Millennial Generation: Relationships between Knowledge, Skills, Attitude, and Behaviour'. Australasian Accounting, Business and Finance Journal, 14(4), 24-37. http://dx.doi.org/10.14453/aabfj.v14i4.3

Dickson, M. A. (2001), 'Utility of No Sweat Labels for Apparel Consumers: Profiling Label-users and Predicting their Purchases', Journal of Consumer Affairs, 35(1),96-119. https://doi.org/10.1111/j.1745-6606.2001.tb00104.x

Dickson, M. A. (2005), 'Identifying and profiling apparel able users'.in Harrison R, Newholm T,and Shaw, D. (eds). The Ethical Consumer, London: SAGE. https://doi.org/10.4135/9781446211991.n11

Dunn, K. I., Mohr, P., Wilson, C. J., \& Wittert, G. A. (2011). Determinants of fast-food consumption. An application of the theory of planned behaviour. Appetite, 57(2), 349-357.

Dunn, D. S., \& Wilson, T. D. (1990). When the stakes are high: A limit to the illusion-of-control effect. Social Cognition, 8, 305- 323. Englewood Cliffs, NJ: Prentice-Hall. https://doi.org/10.1521/soco.1990.8.3.305

Fishbein, M., \& Ajzen, I. (1975). Belief, Attitude, Intention and Behaviour: An Introduction to Theory and Research. Addison-Wesley.

.Fornell, C., \& Larcker, D. F. (1981). Evaluating structural equation models with unobservable variables and measurement error. Journal of Marketing Research, 18, 39-50. https://doi.org/10.1177/002224378101800104

Fukukawa, K. (2003). A Theoretical Review of Business and Consumer Ethics Research: Normative and Descriptive Approaches. The Marketing Review, 3, 381-401. https://doi.org/10.1362/146934703771910035

Hair, J. F., Black, W.C., Babin, B. J., Anderson, R. E., \& Tatham, R. L. (2011). Multivariate Data Analysis. Pearson Prentice Hall.

Hassan, L. M., Shiu, E., \& Shaw, D. (2016). Who says there is an intention-behaviour gap? Assessing the empirical evidence of an intention-behaviour gap in ethical consumption. Journal of Business Ethics, 136(2), 219-236. https://doi.org/10.1007/s10551-014-2440-0

Kaiser, F. G., Ranney, M., Hartig, T., \& Bowler, P. A. (1999). Ecological behaviour, environmental attitude, and feelings of responsibility for the environment. European Psychologist, 4(2), 59-74. https://doi.org/10.1027/1016-9040.4.2.59

Kaur, J. (2014), Customer Relationship Management. Dreamtech Press.

Kaur, J., Duggal, V., \& Suri, S. (2018). To study the Factors effecting Purchase of Green products and their relation to the Purchase decision of Green products for Generation $\mathrm{Z}$ in India'. Journal of Asia Entrepreneurship and Sustainability, 4(2). 
Kim, Y. H., Kim, D. J., \& Wachter, K. (2013). A study of mobile user engagement (MoEN): Engagement motivations, perceived value, satisfaction, and continued engagement intention. Decision Support Systems, 4(2). https://doi.org/10.1016/j.dss.2013.07.002

Klockner, C. A., \& Blobaum, A. (2010). A comprehensive action determination model: Toward a broader understanding of ecological behaviour using the example of travel mode choice. Journal of Environmental Psychology, 30, 574-586. https://doi.org/10.1016/j.jenvp.2010.03.001

Kraft, P. J., Rise, S., \& Roysamb, E. (2005). Perceived Difficulty in the Theory of Planned Behaviour: Perceived Behavioural Control or Affective Attitude?. British Journal of Social Psychology, 44, 479-496. https://doi.org/10.1348/014466604X17533

Kumar, B., Manrai, A. K., \& Manrai, L. A. (2017). Purchasing behaviour for environmentally sustainable products: a conceptual framework and empirical study. Journal of Retail and Consumer services, 34, 1-9. https://doi.org/10.1016/j.jretconser.2016.09.004

McKinsey (2020). The State of Fashion 2020'. Retrieved from https://www.mckinsey.com/ /media/McKinsey/Industries/Retail/Our\%20Insights/The\%2 0state \%20of\%20fashion\%202020\%20Navigating\%20uncertainty/The-State-of-Fashion2020-vF.ashx Mckinsey 2020.Accessed on 15th Feb 2020.

Newholm, T. (2005). Case Studying Ethical Consumers' Projects and Strategies', in R. Harrison, T. Newholm and D. Shaw (eds.).The Ethical Consumer. Sage Publications. London.

Nigbur, D., Evanthia, L., \& Uzzell, D. (2010). Attitudes, norms, identity and environmental behaviour: Using an expanded theory of planned behaviour to predict participation in a kerbside recycling programme. British Journal of Social Psychology, 49, 259284. https://doi.org/10.1348/014466609X449395

Notani, A. S. (1998). Moderators of Perceived Behavioural Control's Predictiveness in the Theory of Planned Behaviour: A Meta-Analysis. Journal of Consumer Psychology, 7(3), 247-271. https://doi.org/10.1207/s15327663jcp0703_02

Ozcaglar-Toulouse, N., Shui, E., \& Shaw, D. (2006). In Search of Fair Trade: Ethical Consumer Decision Planned Behaviour: A Meta-Analysis. Journal of Consumer Psychology, 7(3), 247-271. https://doi.org/10.1111/j.1470-6431.2006.00532.x

Schlegelmilch, B. B., Bohlen, G. M., \& Diamantopoulos, A. (1996). The link between green purchasing decisions and measures of environmental consciousness. European Journal of Marketing, 30(5),35 - 55. https://doi.org/10.1108/03090569610118740

Sethi, R., Wadera, D., \& Kaur, J. (2017). Purchase Intention Survey of Millennials Towards Online Fashion Stores. Academy of Marketing Studies Journal, 22(1). https://www.proquest.com/scholarly-journals/purchase-intention-survey-millennialstowards/docview/2046107437/se-2?accountid=133056

Shaw, D., \& Clarke, I. (1999). Belief formation in ethical consumer groups: an exploratory study. Marketing Intelligence and Planning, 17(2), 109-119. https://doi.org/10.1108/02634509910260968 
Shaw, D., \& Connolly, J. (2006). Identifying Fair Trade in Consumption Choice. Journal of Strategic Marketing, 14(4), 353-368. https://doi.org/10.1080/09652540600960675

Shaw, D., \& Shui, E. (2002). An Assessment of Ethical Obligation and Self-Identity in Ethical Consumer Decision-Making: A Structural Equation Modelling Approach. International Journal of Consumer Studies, 26(4), 286-293. https://doi.org/10.1046/j.1470$\underline{6431.2002 .00255 . x}$

Shaw, D., Edward, S., \& Ian, C., (2000). The Contribution of Ethical Obligation and Self-identity to the Theory of Planned Behaviour: An Exploration of Ethical Consumers. Journal of Marketing Management, 16(8), 879-94. https://doi.org/10.1362/026725700784683672

Sheeran, P., Trafimow, D., \& Armitage, C. J. (2003). Predicting Behaviour from Perceived Behavioural Control: Tests of the Accuracy Assumption of the Theory of Planned Behaviour. British Journal of Social Psychology, 42, 393410. https://doi.org/10.1348/014466603322438224

Sheeran, P., Trafimow, D., \& Armitage, C. J. (2003). Predicting Behaviour from Perceived Behavioural Control: Tests of the Accuracy Assumption of the Theory of Planned Behaviour. British Journal of Social Psychology, 42, 393410. https://doi.org/10.1348/014466603322438224

Scholz, U., Schuz, B., Ziegelmann, J. P., Lippke, S., \& Schwarzer, R. (2008). Beyond behavioural intentions: Planning mediates between intentions and physical activity. British Journal of Health Psychology, 13, 479-494. https://doi.org/10.1348/135910707X216062

Taber, K. S. (2016). The Use of Cronbach's Alpha When Developing and Reporting Research Instruments In Science Education. Research in Science \& Education, 48, 1273-1296. https://doi.org/10.1007/s11165-016-9602-2

Tomolillo, D., \& Shaw, D. (2004). Undressing the Ethical Issues in Fashion: A Consumer Perspective'. In Christopher Moore, Margaret Bruce, and Grete Birtwistle (ed.), Cases in International Retail Marketing, (pp. 141-154), Elsevier, UK. https://doi.org/10.4324/9780080473123-20

Trafimow, D., Sheeran, P., Conner, M., \& Finlay, K. (2002). Evidence that perceived behavioural control is a multidimensional construct: Perceived control and perceived difficulty. British Journal of Social Psychology, 41, 101- 122. https://doi.org/10.1348/014466602165081

Venkatesh, V., Morris, M. G., Davis, G. B., \& Davis, F. D. (2003). User acceptance of information technology: toward a unifying view. MIS Quarterly, 27, 425-478. https://doi.org/10.2307/30036540

Vermeir, I., \& Verbeke, W. (2006). Sustainable food consumption: exploring the consumer attitude-behavioural intention gap. Journal of Agricultural and Environmental Ethics,19(2),1-14.https://doi.org/10.1007/s10806-005-5485-3

Vohra, A., \& Bhardwaj, N. (2019). Customer engagement in an e-commerce brand community: An empirical comparison of alternate models. Journal of Research in Interactive Marketing. https://doi.org/10.1108/JRIM-01-2018-0003 
Vohra, A., \& Bhardwaj, N. (2017). From active participation to engagement in online communities: Analysing the mediating role of trust and commitment. Journal of Marketing Communications. https://doi.org/10.1080/13527266.2017.1393768

Wadera, D. \& Kaur, J. (2019). Comparing sustainability practices in luxury brands: A conceptual model. Journal of Asia Entrepreneurship \& Sustainability, 15(3).

Williams, S., John, T., \& Melanie, H. (2005). The Ethical Consumerism Report 2005. UK: The Cooperative Bank. 